\begin{tabular}{cc|c}
\hline Tar. Bil. Der. & Journal of Agricultural Sciences \\
& $\begin{array}{c}\text { Dergi web sayfası: } \\
\text { www.agri.ankara.edu.tr/dergi }\end{array}$ & Journal homepage: \\
& www.agri.ankara.edu.tr/journal
\end{tabular}

\title{
Influence of Harvesting on Quality of Alfalfa Forage used for Haylage and Hay
}

\author{
Stanısavljevıć RADE ${ }^{\mathrm{a}}$, Vuković ALEKSANDAR ${ }^{\mathrm{b}}$, Barać SAŠA ${ }^{\mathrm{b}}$, Radojevıć RADE ${ }^{\mathrm{c}}$, Đokıć DAGOSLAV ${ }^{\mathrm{d}}$, \\ Petrović V. DRAGAN ${ }^{c}$ \\ aInstitute for Plant Protection and Environment, Teodora Drajzera 9, 11040, Belgrade, SERBIA \\ ${ }^{\boldsymbol{b}}$ University of Priština, Faculty of Agriculture, Kopaonička b.b., 38228, LEŠAK \\ ${ }^{c}$ University of Belgrade, Faculty of Agriculture, Department for Agricultural Engineering, Nemanjina 6, Belgrade, SERBIA \\ dInstitute for Forage Crops, Globoder b.b., 37251, Kruševac, SERBIA
}

\section{ARTICLE INFO}

Research Article

DOI: 10.15832 /ankutbd.434398

Corresponding Author: Petrović V. DRAGAN, E-mail: epetrodr@agrif.bg.ac.rs, Tel: (+381) 63254752

Received: 18 June 2018, Received in Revised Form: 16 August 2018, Accepted: 08 September 2019

\begin{abstract}
The paper presents the three years efficiency results (2011-2013) of the work and ways of harvesting (three types of mowers, with or without spreading the forage) influencing the quality of the forage (the content of crude protein and crude fiber) during the three days drying process. These results indicate that the harvesting method can strongly affect the work efficiency, energy consumption, the forage drying intensity and the quality of forage used for hay and haylage preparation. The best quality of the forage was achieved when a drum rotating mower PÖTTINGER CAT 185 was used. Negative correlation was found between content of crude protein and the crude fibre content, depending on the type of mower, varying in the range between $r=-0.978$ and $r=-0.882$ (PÖTTINGER CAT $185 r=-0.882 \mathrm{P} \leq 0.05$ to JF STOLL SB $200 \mathrm{r}=-0.978 \mathrm{P} \leq 0.001)$.
\end{abstract}

Keywords: Mowers; Cutting; Drying; Crude protein; Crude fiber

(C) Ankara Üniversitesi Ziraat Fakültesi

\section{Introduction}

In many regions of the world, alfalfa (Medicago sativa) is an important fodder plant for the provision of high-quality animal feed for ruminant (Khadda et al 2015; Ahmad et al 2016). It is very adaptable to the environmental conditions, which enables a wide area of growing (in the northern hemisphere it is grown up to $69^{\circ} \mathrm{N}$ - in Scandinavian countries, and in the south up to $45^{\circ} \mathrm{S}$ (New Zealand), as well as on $55^{\circ} \mathrm{S}$ in Argentina and Chile (Ivanov 1988). Its preference lies in the fact that it is used in different ways: fresh, hay, silage, haylage and/or for pasturage. It has high nutritive values. All of this gives it the title of Queen of forage crops. High variability of yield and quality of alfalfa forage is defined in the world, be it influenced by genetics, cultivation technology, harvesting manner (Brummer 2004; Ahmad et al 2016; Karayilanli \& Ayhan 2016), and seed yield (Stanisavljević et al 2012; Zhang et al 2017). Bagg (2004) recommends manipulation of the mowed alfalfa mass of humidity up to $50 \%$ using a rotary 
spreader. Subsequent treatment of the mass with a lower percentage of humidity results in a large loss of leaves. In the southeastern and southern Europe, alfalfa is mainly used for drying and haymaking, but in smaller areas it is used for storing haylage. Given that the process of hay storing and/or alfalfa haylage is done on the fields, it is largely dependent on climatic factors. Based on rainfall simulation, Coblentz \& Muck (2012) reported consistent reductions in concentrations of WSC and starch. However, changes in WSC were relatively modest, and postwetting concentrations of WSC could be buoyed by hydrolysis of starch. In addition, they found much less desirable indicators of ensilability, when forages were subjected to natural rainfall events followed by prolonged exposure under field conditions. Therefore, the selection of the appropriate mowing apparatus and timely alfalfa mowing is essential for protein and fibre content, being the most important parameter of the forage quality. Mowers are agricultural machines that consume a lot of energy, and the special attention has to be paid to optimal energy consumption and quality of work (Hosseini \& Shamsi 2012).

The aim of this study was to determine the impact on yield, quality of forage and energy consumption by examining the ways of alfalfa harvesting.

\section{Material and Methods}

Field experiment was established in Central Serbia, $\left(43^{\circ} 33^{\prime} 33^{\prime \prime} \mathrm{N} ; 21^{0} 12^{\prime} 53^{\prime \prime} \mathrm{E}\right)$ on alfalfa Cultivar Kruševacka-28 in the third to fifth year of use when in the phase $1 / 2$ of flowering. Random block system with three repetitons over the plots of $30 \mathrm{~m} \times 10$ $\mathrm{m}=300 \mathrm{~m}^{2}$ was used. Cultivar is characterized by high genetic potential for yield of forage (over $80 \mathrm{t}$ $\mathrm{ha}^{-1}$ ) and dry matter (over $20 \mathrm{t} \mathrm{ha}^{-1}$ ). It is suitable for intensive production, achieves 6 cuts per year with applied irrigation. This cultivar is tolerant to lodging, frequent cutting and possesses a high resistance to low temperatures and drought, providing excellent forage quality: crude protein content is $20-22 \mathrm{~g} \mathrm{~kg}^{-1}$ and crude fiber (CF) about $32 \mathrm{~g} \mathrm{~kg}^{-1}$ (Institute for Forage Crops 2011).
Alfalfa seeding have been performed following classical soil tillage system, after deep autumn plowing and secondary soil tillage, characterised with a seed norm of $20 \mathrm{~kg} \mathrm{~h}^{-1}$ during each experimental year, the mineral fertilizer consisting of $8 \%(\mathrm{~N}): 16 \%\left(\mathrm{P}_{2} \mathrm{O}_{5}\right): 24 \%\left(\mathrm{~K}_{2} \mathrm{O}\right) 150 \mathrm{~kg} \mathrm{~h}^{-1}$ was deposited over the plot.

At the first alfalfa harvest during $2011\left(\mathrm{~A}_{1}\right)$, $2012\left(\mathrm{~A}_{2}\right), 2013\left(\mathrm{~A}_{3}\right)$ - factor $\mathrm{A}$, three mowers were studied: IMT $627667\left(\mathrm{~B}_{1}\right)$, whose cutting apparatus consists of fixed and mobile part. Fixed part consists of steel beam with fingers. Each finger has a counter knife attached it by clinch. The movable part is a rod with moving blades having a straight line and return movement, Pottinger CAT $185\left(\mathrm{~B}_{2}\right)$, rotary mower with two drums that work in pairs. Each drum has three movable blades which cut the stem cut off with free and high velocity of the blades $\left(60\right.$ to $\left.80 \mathrm{~m} \mathrm{~s}^{-1}\right)$, and JF-STOLL SB $200\left(\mathrm{~B}_{3}\right)$, rotary mower with five disks with two knives each - factor B. After cutting, forage was spread on one half of the plot during the first two days $\left(\mathrm{C}_{2}\right)$, whereas on the other half it was dried without spreading $\left(C_{1}\right)$ (factor C). Samples of forage were analyzed immediately after cutting $\left(\mathrm{D}_{0}\right)$, on the cutting day after $8^{\mathrm{h}}\left(18^{\mathrm{h}}\right)\left(\mathrm{D}_{1}\right)$, on the second day at $18^{\mathrm{h}}\left(\mathrm{D}_{2}\right)$ and on the third day at $18^{\mathrm{h}}\left(\mathrm{D}_{3}\right)$, factor $\mathrm{D}$ time after cutting. Speed is determined by the chronometer method based on distance travelled per unit of time. The quality of work is determined through the working width, the stems cutting height and losses while mowing, assuming that the optimum cutting height for alfalfa is $6 \mathrm{~cm}$. Stem cutting height is determined by the on-site determination of loss, by measuring the height of stubble for each probe (probe within three replicates) on a suitable surface. The mean values are determined for each trial on the basis of obtained parameters. During mowing, losses were measured on the surface of one length meter of swath in working width, of tested mowers, on the same place where the height of cut was determined. Total losses $\left(\mathrm{L}_{\Sigma}[\%]\right)$ represent the sum of the losses incurred due to the cut height $\left(\mathrm{L}_{\mathrm{Hcut}}[\%]\right)$ and losses incurred due to chopping $\left(\mathrm{L}_{\text {Chop }}[\%]\right)$. After cutting, humidity of the 
mowed mass was measured on the first, second and third day at $18 \mathrm{~h}$ (after drying in a drier at $105^{\circ} \mathrm{C}$ ), and the forage quality parameters in the dry matter were measured: Crude protein $\left(\mathrm{CP}, \mathrm{g} \mathrm{kg}^{-1}\right)$, using the Kjeldahl method (AOAC 1990) and crude fibre $\left(\mathrm{CF}, \mathrm{g} \mathrm{kg}^{-1}\right.$ ), using the Weende method (AOAC 1990).

Statistical analysis of forage quality: analysis of variance (ANOVA F-test) was applied to determine the influence of the factors, whereas Tukey's Multiple Range test was used for assessing the influence of the middle of the treatment. The relationship between traits was established by the Pearson's Correlation Test (r). The program Minitab 16.1.0 was used for data processing.

\section{Results and Discussion}

Under the agroecological conditions in South East Europe, alfalfa is generally mowed four times, wherein the first cutting contributes to an overall forage yield with about 50\% (Strbanović et al 2015). Therefore, this work depicted the results of the first cut. During experiment (2011-2013), there was no rainfall in the alfalfa drying period $\left(\mathrm{D}_{1}-\mathrm{D}_{3}\right)$, and the temperature had not varied for more than $2 \%$. Also, the relative humidity did not vary for more than $2 \%$ (Figure 1).

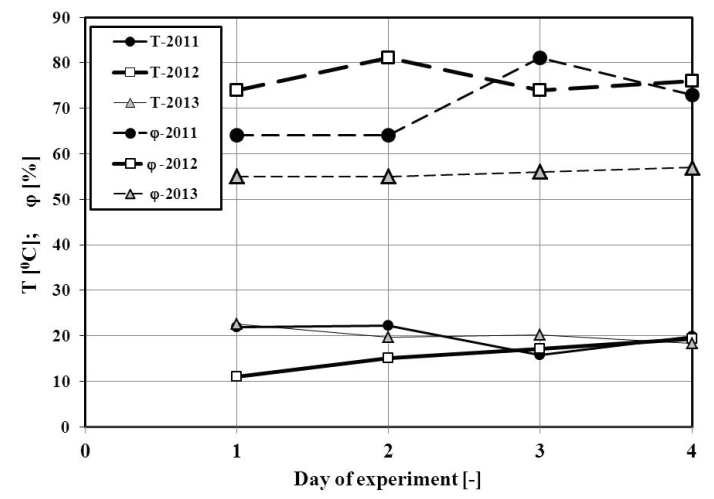

Figure 1- Atmospheric conditions during experimental mowing: the mean temperature $\mathrm{T}\left[{ }^{0} \mathrm{C}\right]$ and relative humidity $\phi[\%]$

\subsection{Work efficiency of the mowers}

In our tests, the maximum value of the utilization coefficient of working swath of $0.97(1.55 \mathrm{~m})$, was found at classical mower in the first year of research. The lowest value of $0.91(1.81 \mathrm{~m})$ was recorded at the rotational disc mower in the third year of research. The cutting height depends on the mower movement speed. The maximum value of the cutting height from $7.25 \mathrm{~cm}$ was recorded at the rotational disc mower in the third year of research, at speed of $12.4 \mathrm{~km} \mathrm{~h}^{-1}$. The minimum value of the cutting height of $5.52 \mathrm{~cm}$ in the first year of research was recorded at rotary mower with drums at speed of $9.1 \mathrm{~km} \mathrm{~h}^{-1}$ (Figure 2). The obtained results are consistent with the results of other researchers (Wiersma \& Wiederholt 2001).

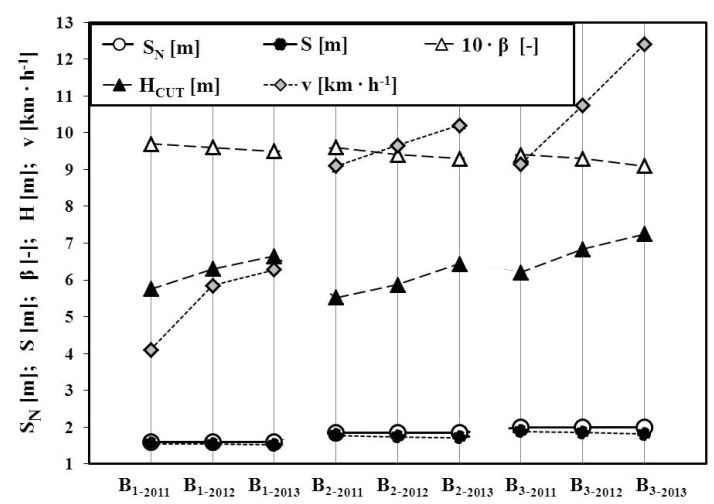

Figure 2- Operational parameters of the harvesters: nominal working swath $S_{\mathrm{N}}[\mathrm{m}]$; achieved working swath $\mathrm{S}[\mathrm{m}]$; coefficient of achieved working swath $\beta$ [-]; cutting height $\mathrm{H}_{\mathrm{CUT}}[\mathrm{m}]$; working speed $\mathbf{v}\left[\mathrm{km} \cdot \mathbf{h}^{-1}\right]$

Figure 3 shows the losses of the tested mowers. Minimum losses of $1.03 \%$ were recorded in conventional mowers in the first year, whereas maximum of $3.03 \%$ were recorded at rotary mowers with drums in the third year of research. The evidenced losses correspond with the results of other researchers (Bagg 2004; Barać et al 2012).

Using variance analysis ( $F$ test) we found that years (factor A) and interactions $\mathrm{AxB}, \mathrm{AxC}, \mathrm{AxD}$ did not seem significant for the moisture content, 


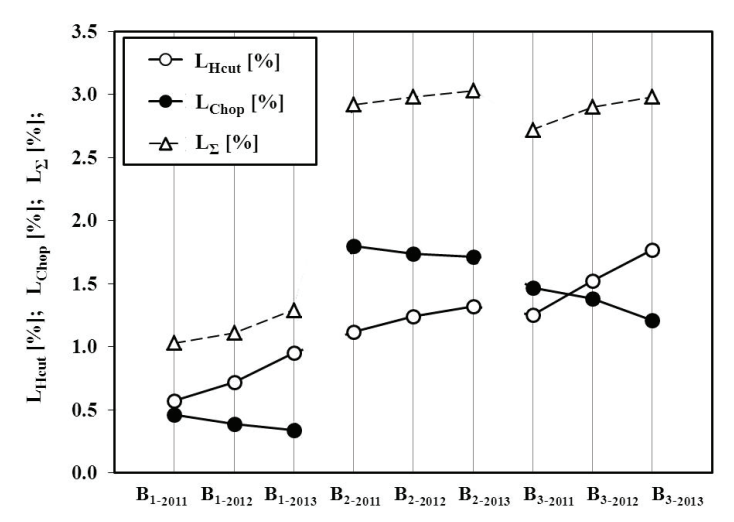

Figure 3- Harvesting losses due to: cutting height $\mathrm{L}_{\mathrm{HCut}}[\%]$, chopping $\mathrm{L}_{\text {Chop }}[\%]$ and total $\mathrm{L}_{\Sigma}[\%]$

crude protein and crude fiber in alfalfa forage (hereinafter the average values for 2011-2013 are given). Influence of different mower (factor B), hay spreading (C) and drying time (D) had significant impact $(\mathrm{P} \leq 0.05$ to $\mathrm{P} \leq 0.001)$, as well as their interaction on the moisture content, crude protein and crude fiber in the alfalfa forage (Table 1).

\subsection{Forage moisture}

Forage moisture should be up to 20\% (Undersander et al 2004) for drying process and hay preparation without additives that can be stored. Optimum moisture content is $55 \%-60 \%$ for making haylage without additives (Dinić \& Djordjević 2005). Due to possible rainfall, it is usefull to make green fodder into stored hay or silage. As expected, moisture ranged from $76 \%\left(\mathrm{~B}_{1}\right)$ to $71 \%\left(\mathrm{~B}_{2}\right.$ and $\mathrm{B}_{3}$ ) immediately after mowing, so that due to high moisture, forage could have not been used even for silage. After eight hours, moisture from the treatments $\mathrm{B}_{1} \mathrm{C}_{1}$ and $\mathrm{C}_{2}(56.8 \%$ and $55.5 \%) \mathrm{B}_{2} \mathrm{C}_{1}$ $(55.1 \%)$ was ideally suited for the preparation of haylage. Forage referred to in the treatment $\mathrm{B}_{3} \mathrm{C}_{2}$ and $\mathrm{B}_{2} \mathrm{C}_{2}(47.7 \%$ and $49.0 \%)$ had a significantly lower moisture $(\mathrm{P} \leq 0.05)$ than forage from $\mathrm{B}_{1} \mathrm{C}_{1}$ $(56.8 \%)$. As expected, in all $\mathrm{B}_{1}-\mathrm{B}_{3}$ treatments of the forage spreading $\left(\mathrm{C}_{2}\right)$, moisture was lower compared to the forage not spread $\left(\mathrm{C}_{1}\right)$ (Table 2).

On the second day of forage drying, moisture between spread and non-spread feed was as follows: $7.6 \%$ for the treatment $\mathrm{B}_{1} ; 6.5 \%$ for the treatment $\mathrm{B}_{2}$ and $4.7 \%$ for $\mathrm{B}_{3}$. However, after two days of drying, the moisture of the applied treatments was high for hay making, but low for haylage, so the different mowers $\left(\mathrm{B}_{1}-\mathrm{B}_{3}\right)$ and forage spreading could not influence enough on forage moisture to make it sufficient for hay storing. After the third day $\left(\mathrm{D}_{3}\right)$ the forage treatment: $\mathrm{B}_{3} \mathrm{C}_{1}$ and $\mathrm{C}_{2}$ (moisture content $18.9 \%$ and $17.3 \%) ; \mathrm{B}_{2} \mathrm{C}_{2}$ (moisture content $18.6 \%$ ), and $\mathrm{B}_{1} \mathrm{C}_{2}$ (moisture content $18.7 \%$ ) met conditions

Table 1- Results of analysis of variance (ANOVA) for forage moisture, crude proteins, crude fiber. Sources of variation: (A), year; (B), type of mower; (C), hay spreader; (D), time after cutting

\begin{tabular}{cccc}
\hline Source of variation & $\begin{array}{c}\text { Forage moisture } \\
(\%)\end{array}$ & $\begin{array}{c}\text { Crude proteins } \\
\left(C P, \mathrm{~kg}^{-1}\right)\end{array}$ & $\begin{array}{c}\text { Crude fibre } \\
\left(\mathrm{CP}, \mathrm{g} \mathrm{kg}^{-1}\right)\end{array}$ \\
\hline Year (A) & $\mathrm{ns}$ & $\mathrm{ns}$ & $\mathrm{ns}$ \\
Type of mower (B) & $*$ & $*$ & $*$ \\
Hay spreader (C) & $* *$ & $*$ & $*$ \\
Time after cutting (D) & $* * *$ & $* * *$ & $* * *$ \\
AxB & $\mathrm{ns}$ & $\mathrm{ns}$ & $\mathrm{ns}$ \\
AxC & $\mathrm{ns}$ & $\mathrm{ns}$ & $\mathrm{ns}$ \\
AxD & $\mathrm{ns}$ & $\mathrm{ns}$ & $\mathrm{ns}$ \\
$\mathrm{BxC}$ & $* *$ & $*$ & $*$ \\
$\mathrm{BxD}$ & $* *$ & $*$ & $*$ \\
$\mathrm{CxD}$ & $*$ & $*$ & $*$ \\
\hline
\end{tabular}

***, significant $\mathrm{F}$ tests at the $\mathrm{P} \leq 0.001$ level of significance; **, significant $\mathrm{F}$ tests at the $\mathrm{P} \leq 0.01$ level of significance; *, significant $\mathrm{F}$ tests at the $\mathrm{P} \leq 0.05$ level of significance; ns, not significant $\mathrm{F}$ tests at the $\mathrm{P} \geq 0.05$ level of significance 
Table 2- Influence of way of alfalfa harvesting to forage moisture during three days of drying

\begin{tabular}{|c|c|c|c|c|c|c|}
\hline \multirow{2}{*}{$\begin{array}{c}\text { Type of } \\
\text { mowers- } B \\
\text { treatmens } \\
B_{1}-B_{3}\end{array}$} & \multicolumn{6}{|c|}{ Forage moisture (\%) } \\
\hline & $\begin{array}{l}\text { Before } \\
\text { cutting }\end{array}$ & $\begin{array}{l}\text { Immediately } \\
\text { after cutting } \\
\left(10^{h}\right) D_{0}\end{array}$ & $C$ & $\begin{array}{c}\text { Cutting day } 18^{\underline{h}} \\
D_{1}\end{array}$ & $\begin{array}{c}\text { Second day } 18^{\underline{h}} \\
\mathrm{D}_{2}\end{array}$ & $\begin{array}{c}\text { Third day } 18^{\underline{h}} \\
D_{3}\end{array}$ \\
\hline \multirow{2}{*}{$\mathrm{B}_{1}$} & \multirow{2}{*}{$78.0^{\mathrm{a}}$} & \multirow{2}{*}{$76.0^{\mathrm{a}}$} & $\mathrm{C}_{1}$ & $56.8^{\mathrm{aA}}$ & $35.0^{\text {a B }}$ & $25.4^{\mathrm{aC}}$ \\
\hline & & & $\mathrm{C}_{2}$ & $55.5^{\mathrm{ab} \mathrm{A}}$ & 27.4 ab B & 18.7 ab C \\
\hline \multirow{2}{*}{$\mathrm{B}_{2}$} & \multirow{2}{*}{$76.0^{\mathrm{a}}$} & \multirow{2}{*}{$71.5^{\mathrm{b}}$} & $\mathrm{C}_{1}$ & $55.1 \mathrm{abA}$ & $33.4^{\text {а в }}$ & $22.0^{\mathrm{aC}}$ \\
\hline & & & $\mathrm{C}_{2}$ & $49.0^{\mathrm{bA}}$ & $26.9^{\text {b в }}$ & $18.6^{\mathrm{bC}}$ \\
\hline \multirow{2}{*}{$\mathrm{B}_{3}$} & \multirow{2}{*}{$75.0^{\mathrm{a}}$} & \multirow{2}{*}{$71.5^{\mathrm{b}}$} & $\mathrm{C}_{1}$ & $50.6 \mathrm{abA}$ & 29.6 ab B & $18.9 \mathrm{abc}$ \\
\hline & & & $\mathrm{C}_{2}$ & $47.7^{\mathrm{bA}}$ & $24.9^{\text {b в }}$ & $17.3^{\mathrm{bC}}$ \\
\hline
\end{tabular}

a, b, (different small letters) significant effect ( $\mathrm{P} \leq 0.05$; Tukey's Multiple Range test) for the column; A, B, C (different capital letters) significant effect $(\mathrm{P} \leq 0.05$; Tukey's Multiple Range test) for the row

for hay making, which can be stored for long time (Undersander et al 2004).

\subsection{The content of crude protein and crude fiber}

Strbanović et al (2017) found the maximum crude protein content of $212 \mathrm{~g} \mathrm{~kg}^{-1}$ dry matter for the researched sorts at the beginning of flowering process, whereas the lowest recorded content 174 $\mathrm{g} \mathrm{kg}^{-1}$ of dry matter. Thus, depending on a sort, the content of CP in the forage varied for $41 \mathrm{~g} \mathrm{~kg}^{-1}$ dry matter. Our research has shown lower levels of crude protein, which can be explained by the fact that mowing was done at a stage when a $1 / 2$ plant was in flowering process. In general, the quality of alfalfa forage got worse as the days of drying passed (the protein content in the alfalfa forage decreased, a crude fibre content increased), which was statistically significant between the first and third day ( $\mathrm{P} \leq 0.05)$ (Table 3 and 4$)$.

Following Fonnesbeck et al (1986) yield loss from soluble nutrients was $9.7 \%$ (losses of $18.8 \%$ available carbohydrate, $10.2 \%$ of crude protein, $19.8 \%$ of lipids and $14.0 \%$ of soluble minerals). Influence of rain damage on hay quality reducing was more expressed than the influence of advancement in maturity.

Table 3- Influence of alfalfa harvesting on crude protein content in dry matter alfalfa forage during the three days of drying

\begin{tabular}{|c|c|c|c|c|}
\hline \multirow{2}{*}{$\begin{array}{c}\text { Type of } \\
\text { mowers- } B \\
\text { treatmens } B_{1}-B_{3}\end{array}$} & \multirow[b]{2}{*}{$C$} & \multicolumn{3}{|c|}{$\mathrm{CP}, \mathrm{g} \mathrm{kg}^{-1}$} \\
\hline & & $\begin{array}{c}\text { Cutting day } 18^{\mathrm{h}} \\
D_{1}\end{array}$ & $\begin{array}{c}\text { Second day } 18^{\underline{h}} \\
\mathrm{D}_{2}\end{array}$ & $\begin{array}{c}\text { Third day } 18 \underline{h} \\
D_{3}\end{array}$ \\
\hline \multirow{2}{*}{$\mathrm{B}_{1}$} & $\mathrm{C}_{1}$ & $163.0^{\mathrm{aA}}$ & $138.4^{\text {ab B }}$ & $125.8^{a b B}$ \\
\hline & $\mathrm{C}_{2}$ & $160.9^{\mathrm{ab} A}$ & $124.4^{\text {b в }}$ & $112.2^{\mathrm{b} \mathrm{в}}$ \\
\hline \multirow{2}{*}{$\mathrm{B}_{2}$} & $\mathrm{C}_{1}$ & $164.8^{\text {a A }}$ & $147.9^{\mathrm{a} \mathrm{AB}}$ & $137.1^{\text {a B }}$ \\
\hline & $\mathrm{C}_{2}$ & $160.5^{\mathrm{ab} A}$ & $139.6^{\text {а в }}$ & $128.6^{\text {a } \mathrm{B}}$ \\
\hline \multirow{2}{*}{$\mathrm{B}_{3}$} & $\mathrm{C}_{1}$ & $157.0^{\mathrm{b} \mathrm{A}}$ & $125.6^{\mathrm{b} B}$ & $125.6^{\mathrm{ab} B}$ \\
\hline & $\mathrm{C}_{2}$ & $158.8^{\mathrm{bA}}$ & $133.7^{\mathrm{ab} \mathrm{AB}}$ & $119.8^{\text {в в }}$ \\
\hline
\end{tabular}

a, b, (different small letters) significant effect ( $\mathrm{P} \leq 0.05$; Tukey's Multiple Range test ) for the column; $\mathrm{A}, \mathrm{B}$, (different capital letters) significant effect $(\mathrm{P} \leq 0.05$; Tukey's Multiple Range test) for the row 
Table 4- Influence of alfalfa harvesting on crude fibre content in dry matter of alfalfa forage during the three days of drying

\begin{tabular}{ccccc}
\hline \multirow{2}{*}{$\begin{array}{c}\text { Type of } \\
\text { mowers- } B\end{array}$} & & \multicolumn{3}{c}{$C F, \mathrm{~kg}^{-1}$} \\
\cline { 3 - 5 } treatmens $B_{1}-B_{3}$ & & $\begin{array}{c}\text { Cutting day 18 } \\
D_{1}\end{array}$ & $\begin{array}{c}\text { Second day 18 } \\
D_{2}\end{array}$ & $\begin{array}{c}\text { Third day 18 } \\
D_{3}\end{array}$ \\
\hline \multirow{2}{*}{$\mathrm{B}_{1}$} & $\mathrm{C}_{1}$ & $34.96_{\mathrm{aB}}$ & $38.35_{\mathrm{aAB}}$ & $39.85_{\mathrm{aA}}$ \\
& $\mathrm{C}_{2}$ & $34.57_{\mathrm{aB}}$ & $37.57_{\mathrm{aAB}}$ & $40.41_{\mathrm{aA}}$ \\
$\mathrm{B}_{2}$ & $\mathrm{C}_{1}$ & $35.24_{\mathrm{aB}}$ & $36.99_{\mathrm{aAB}}$ & $38.45_{\mathrm{aA}}$ \\
& $\mathrm{C}_{2}$ & $34.59_{\mathrm{aB}}$ & $36.02_{\mathrm{aAB}}$ & $39.26_{\mathrm{aA}}$ \\
& $\mathrm{C}_{1}$ & $35.28_{\mathrm{aB}}$ & $38.53_{\mathrm{aAB}}$ & $39.55_{\mathrm{aA}}$ \\
$\mathrm{B}_{3}$ & $\mathrm{C}_{2}$ & $34.81_{\mathrm{aB}}$ & $37.58_{\mathrm{aAB}}$ & $40.39_{\mathrm{aA}}$ \\
\hline
\end{tabular}

a, b, (different small letters) significant effect ( $\mathrm{P} \leq 0.05$; Tukey's Multiple Range test) for the column; A, B, (different capital letters) significant effect $(\mathrm{P} \leq 0.05$; Tukey's Multiple Range test) for the row

The highest contents of crude proteins was recorded $8^{\mathrm{h}}$ after mowing $\left(\mathrm{D}_{1}\right)$, on the second $\left(D_{2}\right)$, and on the third day $\left(D_{3}\right)$ from the treatment of $\mathrm{B}_{2} \mathrm{C}_{1}$. The crude protein content was lower from treatments with the spread forage, as a consequence of leaves loss (having the highest protein content) during the mass spreading. (Table 3).

Influence of mower had no statistically significant effect after any time $\left(\mathrm{D}_{1}-\mathrm{D}_{3}\right)$ on the crude fibre content (Table 4). According to Strbanović et al (2017) the average value of the crude fibre content for fifteen alfalfa sorts is 275 $\mathrm{g} \mathrm{kg}^{-1}$ with differences of $99 \mathrm{~g} \mathrm{~kg}^{-1}$ of dry matter, caused by impact of a sort, and the total variability expressed by the coefficient of variation $10.48 \%$. It also indicates a high impact on the exploitation phase of the crude fiber content.

After application of various mowers for the collection of alfalfa forage, a negative correlation between the content of crude protein and crude fiber was found, but of different intensity $(\mathrm{P} \leq 0.01$ $\mathrm{B}_{1} ; \mathrm{B}_{2} \mathrm{P} \leq 0.05 ; \mathrm{B}_{3} \mathrm{P} \leq 0.001$ ) (Table 5). The results of the negative interdependent correlation $(\mathrm{P} \leq 0.001)$ between content of protein and cellulose are consistent with the results of Heuze et al (2013), Strbanović et al (2017).
Table 5- Coefficient of simple correlation ( $r$ ) between the content of crude protein and crude fiber content in the forage cut by different mowers $(n=6)$

\begin{tabular}{cc}
\hline $\begin{array}{c}\text { Type of mowers- } B \\
\text { tretmani } B_{1}-B_{3}\end{array}$ & $r$ \\
\hline $\mathrm{B}_{1}$ & $-0.929 * *$ \\
$\mathrm{~B}_{2}$ & $-0.882 *$ \\
$\mathrm{~B}_{3}$ & $-0.978 * * *$ \\
\hline Statistical significance level; *, $\mathrm{P} \leq 0.05 ; * *, \mathrm{P} \leq 0.01 ; * * *, \mathrm{P} \leq 0.001$
\end{tabular}

\section{Conclusions}

If the alfalfa forage is used to store haylage under the given conditions and in similar regions throughout the world, ten hours are sufficient if the collection is performed by a rotary mower with a drum PÖTTINGER CAT $185\left(\mathrm{~B}_{2}\right)$ or less, using a rotary device with discs JF-STOLL SB $200\left(\mathrm{~B}_{3}\right)$ with spreading. For hay storing (humidity under $20 \%$ ), the application of a rotary device with discs STOLL JF-SB $200\left(\mathrm{~B}_{3}\right)$ provides moisture, be the forage spread or not. That is also provided by the other two mowers $\left(\mathrm{B}_{1}\right.$ and $\left.\mathrm{B}_{2}\right)$, with hay spreading $\left(\mathrm{C}_{2}\right)$. The best forage quality was achieved by mower PÖTTINGER CAT $185\left(\mathrm{~B}_{2}\right)$, which is reflected in the highest crude protein content and the lowest dependence correlation with the crude fibre content $(\mathrm{r}=-0,882 ; \mathrm{P} \leq 0.05)$. 


\section{Acknowledgements}

The investigation published in this paper is a part of the project "Improvement of biotechnological procedures as a function of rational utilization of energy, agricultural products productivity and quality increase" financed by the Ministry of Education and Science of the Republic of Serbia, grant No TR-31051.

\begin{tabular}{|ll|}
\hline \multicolumn{2}{|c|}{ Abbreviations and Symbols } \\
\hline$r$ & Index of correlation \\
$P$ & Signifficance level \\
$L_{\Sigma}$ & Total losses, (\%) \\
$L_{\text {Hcut }}$ & Cut-height losses, $(\%)$ \\
$\mathrm{L}_{\text {Chop }}$ & Chopping losses, $(\%)$ \\
$C P$ & Crude protein content, $\left(\mathrm{g} \mathrm{kg}^{-1}\right)$ \\
$C F$ & Crude fibre content, $\left(\mathrm{g} \mathrm{kg}^{-1}\right)$ \\
\hline
\end{tabular}

\section{References}

Ahmad J, Iqbal A, Ayub M \& Akhtar J (2016). Forage yield potential and quality attributes of alfalfa (Medicago sativa L.) under various agro-management techniques. Journal of Animal \& Plant Sciences 26(2): 465-474

AOAC (1990). Official methods of the association of official analytical chemists. Agricultural chemicals, contaminants, drugs. Volume one. Fefteenth Edition, AOAC, Inc., Arlington, Virginia

Bagg J (2004). Cutting, Conditioning \& Raking For Faster Hay Drying. Ministry of Agriculture \& Food, Ontario

Barać S, Vuković A, Milenković B \& Biberdžić M (2012). Testing results of mower with different cutting devices in alfalfa mowing. Research Journal of Agricurtural Science 4(1): 241-248

Brummer E (2004). Applying genomics to alfalfa breeding programs. Crop Science 44: 1904-1906

Coblentz W K \& Muck R E (2012). Effects of natural and simulated rainfall on indicators of ensilability and nutritive value for wilting alfalfa forages sampled before preservation as silage 1. Journal of Dairy Science 95(11): 6635-6653

Dinić B \& Djordjević N (2005). Preparation and use of silage,. Institute for research in agriculture "Serbia", Belgrade, pp. 1-126
Fonnesbeck P V, De Hernandez M G, Kaykay J M \& Saiady M Y (1986). Estimating yield and nutrient losses due to rainfall on field-drying alfalfa hay. Animal Feed Science and Technology 16(1-2): 7-15

Heuze V, Tran G, Boval M, Lebas F, Lessire M, Noblet J \& Renaudeau D (2013). Alfalfa (Medicago sativa), Feedipedia.org.aprogramme by INRA, CIRAD, AFZ and FAO

Hosseini S \& Shamsi M (2012). Performance optimization of a rotary mower using Taguchi method. Agronomy Research Biosystem Engineering 1: 49-54

Institute for Forage Crops (2011). Medicago sativa L., Kruševac, Serbia. Retrieved in May, 18, 2018 from http://www.ikbks.com/?portfolio=lucerka

Ivanov I (1988). Alfalfa. Published by Oxonian Press Pvt. New Delhi

Karayilanli E \& Ayhan V (2016). Investigation of feed value of alfalfa (Medicago sativa L.) harvested at different maturity stages. Legume Research 39(2): 237-247

Khadda S B, Lata K, Kumar R, Jadav K J \& Rai K A (2015). Performance of lucerne (Medicago sativa) under semi-arid ecosystem of Central Gujarat. Indian Journal of Agricultural Sciences 85(2): 199-202

Stanisavljević R, Beković D, Đukić D, Stevović V, Terzić D, Milenković J \& Đokić D (2012). Influence of plant density on yield components, yield and quality of seed and forage yields of alfalfa varieties. Romanian Agricultural Research 29: 245-254

Strbanović R, Simić A, Poštić D, Živanović T, Vučković S, Pfaf-Dolovac E \& Stanisavljević R (2015). Yield and morpnological traits in alfalfa varieties of different origin. Legume Research 38(4): 434-441

Strbanović R, Stanisavljević R, Đukanović L, Poštić D, Marković J, Gavrilović V \& Dolovac N (2017). Variability and correlation of yield and forage quality in alfalfa varieties of different origin. Journal of Agricultural Sciences 23(1): 128-137

Undersander D, Becker R, Cosgorve D, Cullen E, Doll J, Grau C, Kelling K, Rice E M, Schmitt M, Sheaffer C, Shewmaker G \& Sulc M (2004). Alfalfa management guide. American Society of Agronomy, Inc, Crop Sciene Sociaty of America pp. 1-66

Wiersma D \& Wiederholt R (2001). Alfalfa cutting height to maximize forafe yield and quality. University of Wisconsin

Zhang W, Xia F, Li Y, Wang M \& Mao P (2017). Influence of year and row spacing on yield component and seed yield in Alfalfa (Medicago sativa L.). Legume Research 40(2): 325-330 